\title{
Parathyroid hormone-related peptide (PTHrP): prokaryotic expression, purification, and preparation of a polyclonal antibody
}

\author{
H.L. Zheng, H. Li, Y.S. Sun, Z.Y. Yang and Q. Yu \\ Key Laboratory of Molecular Biology for Agriculture, \\ College of Animal Science and Technology, \\ Northwest Agriculture and Forestry University, Yangling, \\ Shaanxi Province, China \\ Corresponding author: H.L. Zheng \\ E-mail: zhenghuiling@nwsuaf.edu.cn
}

Genet. Mol. Res. 13 (3): 6448-6454 (2014)

Received June 20, 2013

Accepted April 29, 2014

Published August 25, 2014

DOI http://dx.doi.org/10.4238/2014.August.25.8

\begin{abstract}
Parathyroid hormone-related peptide (PTHrP) plays important roles in promoting cancer occurrence and in the development of bone metastases. To increase our knowledge of the biological functions of PTHrP, the prokaryotic expression vector pET-PTHrP was successfully constructed and the His-PTHrP fusion protein was expressed in Escherichia coli. Anti-PTHrP polyclonal antibody was then prepared from rabbits. Finally, the goat tissue expression profile of PTHrP was analyzed by Western blot with the anti-PTHrP polyclonal antibody. The results showed that the expression of PTHrP in goat mammary glands was significantly higher than that in other organs. This indicates that PTHrP may play important roles in the goat mammary gland. The antibody prepared will be a useful tool for detecting PTHrP and will be valuable in future studies investigating the role of PTHrP in calcium metabolism in the goat model.
\end{abstract}

Key words: Goats; Parathyroid hormone-related peptide;

Polyclonal antibody; Prokaryotic expression; Tissue expression profile 


\section{INTRODUCTION}

Parathyroid hormone-related protein (PTHrP) was first identified as a tumor product causing humoral hypercalcemia of malignancy (Philbrick et al., 1996). PTHrP and PTH are encoded by related genes that are part of a larger PTH gene family (Ono et al., 2012). PTHrP has a variety of biological functions, such as delaying the incidence of osteoporosis by stimulating renal tubular calcium reabsorption, promoting bone cell differentiation and bone formation (Weiss et al., 2010), and enhancing cell tolerance in harsh environments. PTHrP can also promote the occurrence of cancer and the development of bone metastases (Downs et al., 2011). In breast cancer cells, PTHrP regulates osteoblast monocyte chemoattractant protein-1 (McP-1), which plays important roles in tumor development, growth, progression, and bone metastasis (Strid et al., 2002; Lu et al., 2007; Li et al., 2011). Kocabagli et al. (1995) reported that the PTHrP level is significantly increased in the colostrum. Stewart et al. (2000) reported that the calcium and PTHrP levels in milk are positively correlated. Therefore, it is reasonable to speculate that PTHrP affects calcium transport in mammary glands.

To explore the mechanism of PTHrP regulation of calcium transport in goat mammary glands, the anti-PTHrP polyclonal antibody was generated and applied. The findings provide a valuable basis for further study of the functions and the molecular mechanisms of PTHrP in relation to calcium deposition during lactation.

\section{MATERIAL AND METHODS}

\section{Construction of the recombinant expression vector pET-PTHrP}

The plasmids pMD-PTHrP and pET-32a (+) (Amersham Biosciences; New York, NY, USA) were digested by the $B g l I I$ and $X h o I$ restriction enzymes, respectively, and purified with a DNA purification kit (KeyGen Biotech; Nanjing, China). PTHrP was then inserted into the $B g l \mathrm{II}$ and $\mathrm{XhoI}$ sites of the prokaryotic expression vector pET-32a (+) with T4 DNA ligase at $16^{\circ} \mathrm{C}$ overnight. The recombinant plasmid, identified by restriction enzyme digestion and DNA sequencing, was designated as pET-PTHrP.

\section{Expression and purification of the PTHrP fusion protein}

The pET-PTHrP plasmid was transformed into Escherichia coli BL21 (DE3) competent cells to produce the expression strain BL-pET-PTHrP. A single colony of $E$. coli BLpET-PTHrP cells was inoculated into $2 \mathrm{~mL}$ Luria broth (LB) medium containing $100 \mathrm{mg} / \mathrm{mL}$ ampicillin at $37^{\circ} \mathrm{C}$ overnight. The cells were then inoculated into $200 \mathrm{~mL}$ fresh LB medium with $100 \mathrm{mg} / \mathrm{mL}$ ampicillin until the optical density $(\mathrm{OD})_{600}$ reached 0.5 . The expression of His-PTHrP was induced by $0.5,1.0$, and $1.5 \mathrm{mM}$ isopropyl-b-D-thiogalactopyranoside (IPTG) for $8 \mathrm{~h}$ at $37^{\circ} \mathrm{C}$. Using the same method, the restructuring BL-pET cells were obtained as controls, and BL-pET-PTHrP cells without induction by IPTG were established as another control. Sodium dodecyl sulfate-polyacrylamide gel electrophoresis (SDS-PAGE) was then conducted to determine the optimum IPTG concentration.

The induced $E$. coli cells were harvested by centrifugation at $2400 \mathrm{x} g$ for $15 \mathrm{~min}$ at $4^{\circ} \mathrm{C}$. Ten milliliters pellet per gram wet weight was suspended in cold phosphate-buffered 
saline (PBS) and ultrasonicated at $4{ }^{\circ} \mathrm{C}$. The pellets containing inclusion bodies were then collected by centrifugation at $2400 \mathrm{~g}$ for $10 \mathrm{~min}$ at $4^{\circ} \mathrm{C}$. The pellet was washed twice with PBS and $8 \mathrm{M}$ urea was added at $37^{\circ} \mathrm{C}$ for $10 \mathrm{~min}$. The supernatant and pellet were then collected by centrifugation at $13,800 \mathrm{~g}$ for $20 \mathrm{~min}$ at $4^{\circ} \mathrm{C}$ and both were subjected to SDS-PAGE. After the gel was stained with $0.25 \mathrm{M} \mathrm{KCl}$ for $10 \mathrm{~min}$, the band of the His-PTHrP fusion protein was cut according to the indicated position of the protein marker and placed in a mortar, pre-cooled with liquid nitrogen, and ground to powder. The powder was collected, PBS was added, and the mixture was stored overnight at $4^{\circ} \mathrm{C}$. The next day, the supernatant was collected by centrifugation at $13,800 \mathrm{~g}$ for $15 \mathrm{~min}$ at $4^{\circ} \mathrm{C}$ and a small portion was subjected to SDS-PAGE.

\section{Preparation of the anti-PTHrP polyclonal antibody}

The preparation of the anti-PTHrP polyclonal antibody was carried out as described in previous reports with some modifications (Ren et al., 2010). Briefly, three New Zealand rabbits were each inoculated with $1 \mathrm{~mL} 1 \mathrm{mg} / \mathrm{mL}$ purified PTHrP protein emulsified with equal amounts Freund's complete adjuvant via subcutaneous injection. Immunization of each rabbit was boosted four times by inoculation of $1 \mathrm{~mL}$ antigen mixed with an equal volume Freund's incomplete adjuvant at 1-week intervals. The antiserum was collected from the blood of the rabbits' heart arteries 10 days after the final injection. The rabbit immunoglobulin $\mathrm{G}$ (IgG) fraction was precipitated from the antiserum with $50 \%$ saturated ammonium sulfate and purified by using DEAE-Sepharose column chromatography. The purified antibody was filtersterilized, and supplied in PBS with $0.02 \%$ sodium azide.

\section{Determination of the anti-PTHrP polyclonal antibody titer by enzyme-linked immunosorbent assay (ELISA)}

The polyclonal antibody titer was determined using indirect ELISA. Briefly, ELISA plates were coated and blocked with 5\% non-fat dry milk in PBS with $0.05 \%$ Tween-20 (PBST) at $37^{\circ} \mathrm{C}$ for $1 \mathrm{~h}$. The wells were incubated with the serially diluted (from 1:100 to 51,200 ) polyclonal antiserum at $37^{\circ} \mathrm{C}$ for $1 \mathrm{~h}$. Following three washings with PBST, the plates were incubated with horseradish peroxidase (HRP)-conjugated goat anti-rabbit IgG (1:4000 diluted in PBST) at $37^{\circ} \mathrm{C}$ for $1 \mathrm{~h}$. After stopping the reaction with $50 \mu \mathrm{L}$ stop buffer, the OD was read at $450 \mathrm{~nm}$ using an ELISA reader.

\section{Specificity detection of the anti-PTHrP polyclonal antibody by Western blot}

The purified His-PTHrP fusion protein was subjected to $12 \%$ SDS-PAGE and transferred to a polyvinylidene fluoride (PVDF) membrane. The PVDF membrane was blocked at $37^{\circ} \mathrm{C}$ for $1 \mathrm{~h}$ with $5 \%$ non-fat dry milk in PBST, followed by incubation with the anti-PTHrP antibody (1:1000 dilution) overnight at $4^{\circ} \mathrm{C}$. After three washings with PBST, the membrane was incubated with HRP-conjugated goat anti-rabbit IgG $\left(1: 4000\right.$ dilution) at $37^{\circ} \mathrm{C}$ for $1 \mathrm{~h}$. Membranes were then rinsed three times and the protein bands were visualized with an enhanced chemiluminescence protocol and the Biochemi Imaging System (UVP; Upland, CA, USA). 


\section{Goat PTHrP tissue expression profile}

A variety of organs were collected, such as the mammary gland, brain, marrow, heart, liver, muscle, lung, hypophysis, and spleen. Each $0.1 \mathrm{~g}$ tissue sample was ground to powder in liquid nitrogen, and $500 \mu \mathrm{L}$ radioimmunoprecipitation assay (RIPA) buffer was added. The solution was centrifuged at $13,800 \mathrm{~g}$ for $20 \mathrm{~min}$ at $4^{\circ} \mathrm{C}$, the supernatant was collected for SDSPAGE, and PTHrP expression was detected by Western blot.

\section{RESULTS}

\section{Construction of the recombinant prokaryotic expression vector pET-PTHrP}

The $P T H r P$ gene was cloned into a prokaryotic expression vector to produce a new recombinant plasmid, pET-PTHrP. It was then identified by digestion and sequencing. Results showed that the goat $P T H r P$ gene was successfully inserted into the pET-32a (+) vector (Figure 1).
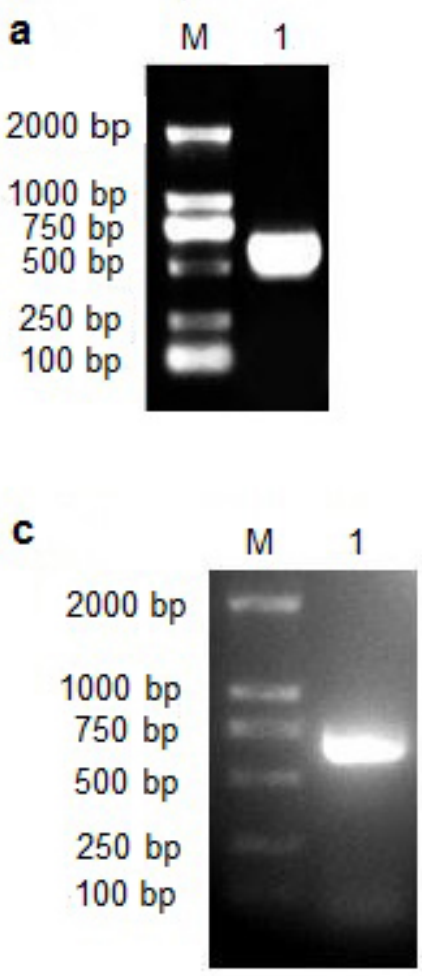
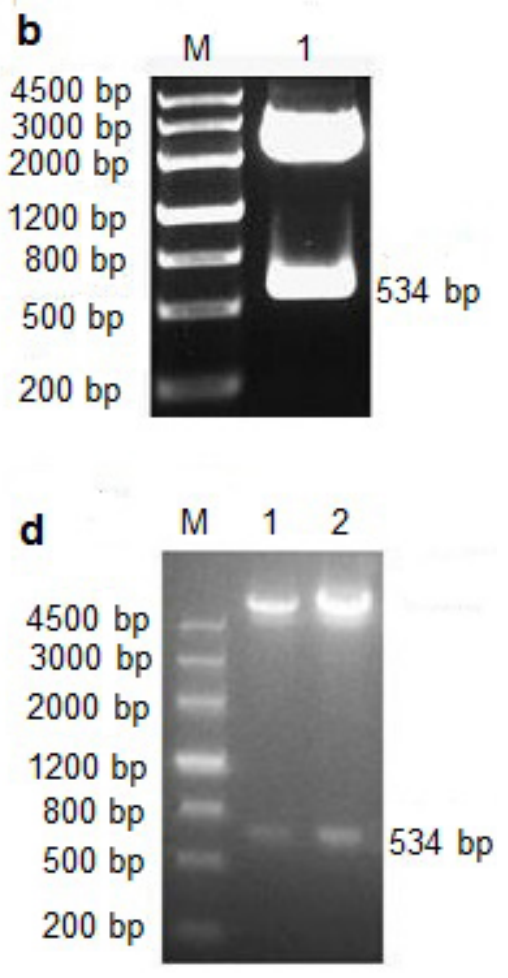

Figure 1. Amplified DNA fragment of $P T H r P$ and verification of recombinant plasmids by digestion with restriction enzymes. (a) Amplified products of $P T H r P$ by PCR with pMD-PTHrP as template. Lane $M=2-\mathrm{kb}$ DNA Marker. (b) pMD-PTHrP digested with $B g l I I$ and XhoI. Lane $M=$ DNA Marker III. (c) Amplified products of PTHrP by PCR with pET-PTHrP as template. Lane $M=2$-kb DNA Marker. (d) pET-PTHrP digested with $B g l I$ and $X h o I$. Lanes 1-2 = pET-PTHrP digested with BglII and XhoI. Lane $M=$ DNA Marker III. 


\section{Expression and purification of the His-PTHrP fusion protein}

The His-PTHrP fusion protein was expressed in the expression strain BL-pET-PTHrP induced at $37^{\circ} \mathrm{C}$ for $4 \mathrm{~h}$ with different IPTG concentrations. The His-PTHrP fusion protein, with an expected $36.5 \mathrm{kDa}$ molecular weight, was detected mainly in the insoluble fraction of the $E$. coli cell lysates. The expression of the fusion protein was the highest using a final concentration of 1.5 mM IPTG, and the purified His-PTHrP fusion protein was obtained (Figure 2).
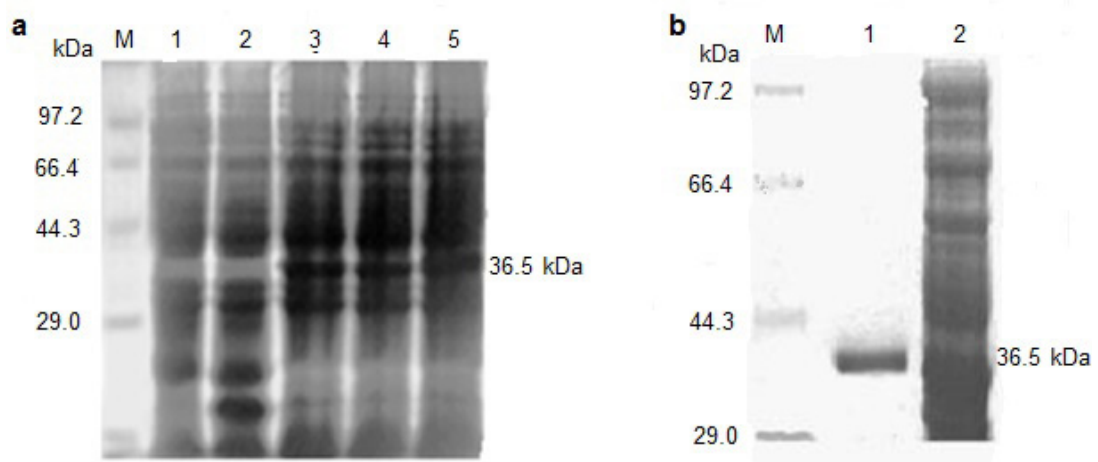

Figure 2. Analysis of pET-PTHrP protein expression in Escherichia coli by SDS-PAGE. (a) SDS-PAGE analysis of pET-PTHrP protein expression induced by different concentrations of IPTG. Lane $1=$ BL-pET cells induced by $1.5 \mathrm{mM}$ IPTG as negative control. Lanes $2-5=$ BL-pET-PTHrP cells induced by IPTG at $0,0.5,1$, and $1.5 \mathrm{mM}$. Lane $M=$ protein mark; (b) SDS-PAGE analysis of purified PTHrP protein (Lane 1) and expressed proteins in the precipitates of cell lysate (Lane 2). Lane $M=$ protein mark.

\section{Detection of the specificity of the anti-PTHrP polyclonal antibody}

The anti-PTHrP polyclonal antibody titer detected by ELISA was more than 1:51,200 (Figure 3). The His-PTHrP fusion protein was detected by Western blot with the anti-PTHrP polyclonal antibody (Figure 4). Results showed that the polyclonal antibody is specific to the PTHrP protein.

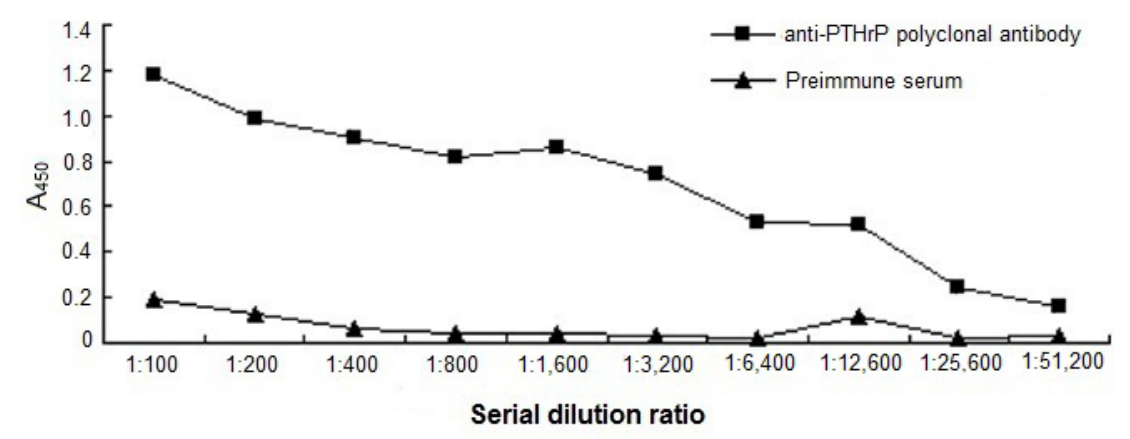

Figure 3. Analysis of anti-PTHrP polyclonal antibody titer by ELISA. 


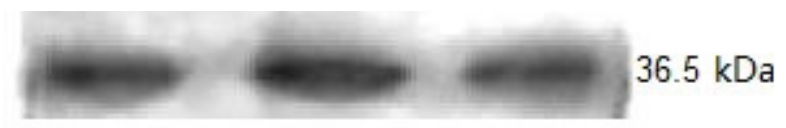

Figure 4. Specificity analysis of the polyclonal antibody by Western blot. The molecular weight of the PTHrP is approximately $36.5 \mathrm{kDa}$.

\section{Tissue expression profile analysis of goat PTHrP}

The Western blot results showed that PTHrP was expressed in the goat mammary gland, kidney, pituitary, brain, heart, liver, bone, and muscle, with the highest expression level observed in the mammary gland. PTHrP was not detected in the pancreas, lung, or stomach (Figure 5).

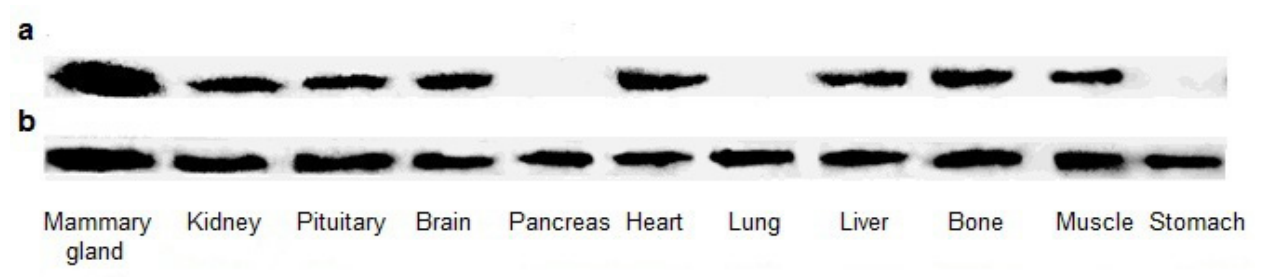

Figure 5. Expression profile of PTHrP protein in tissues analysed by Western blot. (a) anti-PTHrP; (b) anti- $\beta$-actin.

\section{DISCUSSION}

PTHrp gene knockout mice present dyschondroplasia, hump, and mammary dysplasia (Toribio et al., 2010). PTHrP induces osteoclast formation, and decreases osteoblast function in diabetes-related osteopenia patients (Lozano et al., 2009). Once the calcium-sensing receptor gene $(\mathrm{CaSR})$ is knocked out, a rat will present tooth and alveolar hyperplasia; however, once PTHrP is injected, the syndrome is relieved (Yao et al., 2007; Sun et al., 2010). Another study showed that milk calcium level increases during lactation are due to the transport of calcium from the bones and blood to the mammary glands, with simultaneous PTHrP level increases in the mammary glands (Mamillapalli et al., 2008; Sun et al., 2010). During lactation, suckling can stimulate the mammary gland to synthesize and secrete PTHrP, and deposition of calcium in the gland is promoted (Mamillapalli et al., 2008). The mechanism may be regulated by the upstream CaSR gene. Thus, the milk calcium level and PTHrP synthesis are positively correlated during lactation (Cao et al., 2009).

In this study, the goat PTHrP gene prokaryotic expression vector pET-PTHrP was successfully constructed and the expression conditions of the His-PTHrP fusion protein were explored. We found that the His-PTHrP fusion protein was most highly expressed in the expression strain BL-pET-PTHrP cells induced with $1.5 \mathrm{mM} \mathrm{IPTG}$ at $37^{\circ} \mathrm{C}$ for $4 \mathrm{~h}$, and the vast majority of the fusion protein was present in the inclusion body precipitate. In the purification process of the fusion protein, target proteins were isolated by excising the gel slices that contained the appropriate bands to obtain sufficient protein in a short period. The PTHrP protein obtained by this method can be used to produce the polyclonal antibody. The PTHrP tissue 
expression profile indicated that the expression of PTHrP was significantly higher in the goat mammary glands than in other body tissues. This indicates that PTHrP may play key roles in goat mammary gland function. The antibody prepared will be a useful tool for detecting PTHrP, and will thus be valuable for studies on the role of PTHrP in calcium metabolism in the goat model.

\section{ACKNOWLEDGMENTS}

Research co-supported by the Natural Science Foundation of Shaanxi Province (\#2010JM3010) and the Special Fund for Agro-Scientific Research in the Public Interest (\#201103038).

\section{REFERENCES}

Cao G, Gu Z, Ren Y, Shu L, et al. (2009). Parathyroid hormone contributes to regulating milk calcium content and modulates neonatal bone formation cooperatively with calcium. Endocrinology 150: 561-569.

Downs TM, Burton DW, Araiza FL, Hastings RH, et al. (2011). PTHrP stimulates prostate cancer cell growth and upregulates aldo-keto reductase 1C3. Cancer Lett. 306: 52-59.

Kocabagli N, Riond JL, Spichiger UE and Wanner M (1995). Parathyroid hormone-related protein and calcium homeostasis during the periparturient period of dairy cows. Am. J. Vet. Res. 56: 380-385.

Li J, Karaplis AC, Huang DC, Siegel PM, et al. (2011). PTHrP drives breast tumor initiation, progression, and metastasis in mice and is a potential therapy target. J. Clin. Invest. 121: 4655-4669.

Lozano D, de Castro LF, Dapia S, Andrade-Zapata I, et al. (2009). Role of parathyroid hormone-related protein in the decreased osteoblast function in diabetes-related osteopenia. Endocrinology 150: 2027-2035.

Lu Y, Cai Z, Xiao G, Keller ET, et al. (2007). Monocyte chemotactic protein-1 mediates prostate cancer-induced bone resorption. Cancer Res. 67: 3646-3653.

Mamillapalli R, VanHouten J, Zawalich W and Wysolmerski J (2008). Switching of G-protein usage by the calciumsensing receptor reverses its effect on parathyroid hormone-related protein secretion in normal versus malignant breast cells. J. Biol. Chem. 283: 24435-24447.

Ono N, Nakashima K, Schipani E, Hayata T, et al. (2012). Constitutively active PTH/PTHrP receptor specifically expressed in osteoblasts enhances bone formation induced by bone marrow ablation. J. Cell Physiol. 227: 408-415.

Philbrick WM, Wysolmerski JJ, Galbraith S, Holt E, et al. (1996). Defining the roles of parathyroid hormone-related protein in normal physiology. Physiol. Rev. 76: 127-173.

Ren X, Wang M, Yin J, Ren Y, et al. (2010). Heterologous expression of fused genes encoding the glycoprotein 5 from PRRSV: a way for producing functional protein in prokaryotic microorganism. J. Biotechnol. 147: 130-135.

Stewart AF, Cain RL, Burr DB, Jacob D, et al. (2000). Six-month daily administration of parathyroid hormone and parathyroid hormone-related protein peptides to adult ovariectomized rats markedly enhances bone mass and biomechanical properties: a comparison of human parathyroid hormone 1-34, parathyroid hormone-related protein 1-36, and SDZ-parathyroid hormone 893. J. Bone Miner. Res. 15: 1517-1525.

Strid H, Care A, Jansson T and Powell T (2002). Parathyroid hormone-related peptide (38-94) amide stimulates ATPdependent calcium transport in the Basal plasma membrane of the human syncytiotrophoblast. J. Endocrinol. 175: 517-524.

Sun W, Sun W, Liu J, Zhou X, et al. (2010). Alterations in phosphorus, calcium and PTHrP contribute to defects in dental and dental alveolar bone formation in calcium-sensing receptor-deficient mice. Development 137: 985-992.

Toribio RE, Brown HA, Novince CM, Marlow B, et al. (2010). The midregion, nuclear localization sequence, and C terminus of PTHrP regulate skeletal development, hematopoiesis, and survival in mice. FASEB J. 24: 1947-1957.

Weiss S, Hennig T, Bock R, Steck E, et al. (2010). Impact of growth factors and PTHrP on early and late chondrogenic differentiation of human mesenchymal stem cells. J. Cell Physiol. 223: 84-93.

Yao S, Pan F and Wise GE (2007). Chronological gene expression of parathyroid hormone-related protein (PTHrP) in the stellate reticulum of the rat: implications for tooth eruption. Arch. Oral Biol. 52: 228-232. 